\title{
INTEGRATED PLANNING FOR SUSTAINABLE BUILDING PRODUCTION - AN EVOLUTION OVER THREE DECADES
}

\author{
Lars-Åke MIKAELSSON ${ }^{\mathrm{a}}$, Johan LARSSON ${ }^{\mathrm{b}}$ \\ ${ }^{a}$ Department of Ecotechnology and Sustainable Building, Mid Sweden University, \\ 83125 Östersund, Sweden \\ ${ }^{b}$ Faculty of Health and Occupational Studies, University of Gävle, \\ Kungsbäcksvägen 47, 80176 Gävle, Sweden
}

Received 09 Jun 2014; accepted 03 Oct 2014

\begin{abstract}
This paper reviews the authors' work on Integrated Planning (IP) as a construction site management tool. IP integrates the different planning skills used by site managers, construction workers and craftspersons into an interactive group which manages a production planning process from the earliest stages to the end of a building project. The studies reviewed in this paper, performed over the last three decades, tested, longitudinally evaluated and refined the IP model for use in modern sustainable building sites. The refined model, Integrated Planning for Sustainable Building Production (SBP), includes the factors: leadership, health and safety, quality management and environmental management.
\end{abstract}

Keywords: Integrated Planning, sustainability, construction site management, time pressure, leadership, health and safety, environmental management, quality management.

\section{Introduction}

This article reviews the development, testing, evaluation and refinement of the Integrated Planning (IP) model for construction site management. This IP model integrates the skills of site managers, construction workers and craftspersons into a unified group that manages a construction process from initial stages to its conclusion. It is based on five consecutive longitudinal studies on production planning, work organization and leadership at Swedish building and construction sites.

The overall study reviewed here is based in part on multiple studies carried out at Lund and Mid Sweden Universities over the past 30 years in cooperation with national and multi-national construction companies. The ultimate goal was to understand how to make a construction project most successful and the outcome sustainable. The aim of the first study was to develop a model for building site management that integrates the knowledge and experience of the employees at a site. Through a second study, the model was improved. A third study was a follow-up study carried out at the request of the Swedish foremen's trade organisation. The aim of the fourth study, was to investigate the status of IP among Swedish national and multinational building and construction companies (Attacus, Peab, Skanska and NCC). The aim of the fifth study, Integrated Planning for Sustainable Building Production, was to formulate a refined model (we call it
SBP) of IP that integrates healthy and effective leadership behaviours in with other sustainability factors. By balancing economic, social and environmental aspects, a construction process can be optimized in terms of costs, profits, participant well-being and the environment.

The original IP model, as shown in Figure 1, can be described as using the following four stages (Mikaelsson et al. 1992): 1. Establishment of a representative planning group; 2. Initial meetings to establish the guidelines; 3. Regular meetings to monitor the planning and construction processes; and 4. Routines for wind-up and follow-up until building sign-off.

At the centre of Figure 1 is the representative planning group made up of formal leaders and employee representatives. These formal and informal leaders operate the process. As shown in the illustration, by working teams that manage their areas of responsibility surround the lead group. The lead group acts as a gear driving the teams - like in the illustration. In this model a building site is a dynamic socio-technical system that is undergoing continuous change (Mikaelsson 1989). There are three dimensions in that dynamic change process: 1) structure planning which focuses on time and technical logistics; 2) planning for the social system (relations) which form around a building site; and 3) the planning for continuous change within a site's socio-technical system (Mikaelsson 2011). This IP model uses continuous

Corresponding author: Lars-Åke Mikaelsson

E-mail:Lars-Ake.Mikaelsson@miun.se 


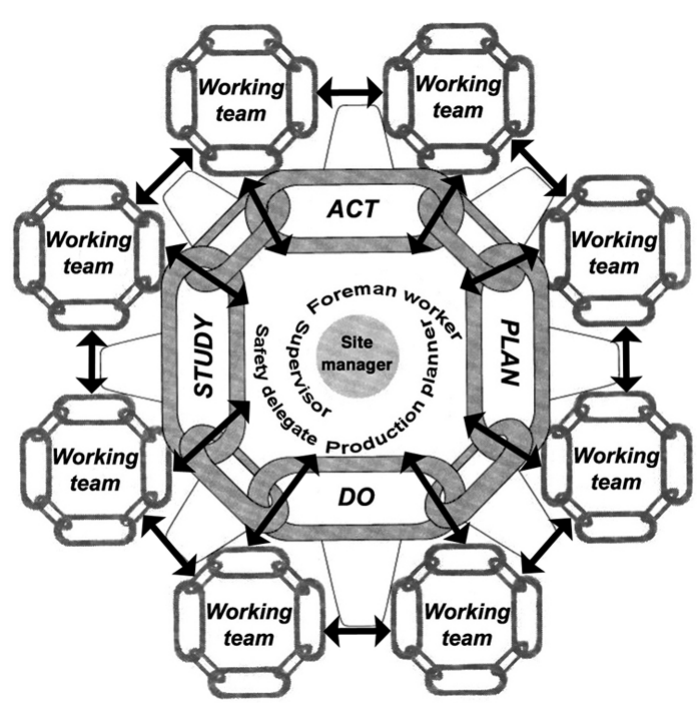

Fig. 1. Integrated Planning (Original model). The site manager is at the centre and energises lower leaders and workers to cooperate and communicate. All the leaders help teams and workers to communicate (Mikaelsson et al. 1992)

and open communication between teams and individuals to identify and respond to changing conditions without the use of a complex organization.

Previous research in the field has emphasized leadership behaviour only as it affects structure planning. One example is "The Last Planner System of Production Control" (Ballard 2000). The IP model is a concept that handles the three dimensions at the same time (Mikaelsson 2011). This is in line with leadership research where findings point to the importance of relation, structure and change being managed at the same time for successful leadership behaviour and successful process outcomes (Arvonen 2002; Yukl 2012).

Through interviews and on-site observations over the course of the studies it became apparent that time, quality and organisation were influencing relationships, building structure and change. Time pressure is a common negative outcome associated with inadequate site management. Each delay is compounded by later delays and problems until deadlines are missed. Time pressure was an outcome indicator in the studies described here. It is defined as how much pressure leaders and workers experience due to common building site time deadlines and it is subjectively measured (Mikaelsson et al. 1992). Time pressure has a dual relevance. Time pressure can create long-term stress due to high job demands that have a negative impact on both health and productivity and might contribute to burnout (see e.g. Karasek, Theorell 1990; Sundin 2009).

Quality can be viewed objectively or subjectively. The objective view is sometimes called standard quality. Crosby (1979) defines this as "conformance to requirements". Crosby's definition is used by this paper where quality is evaluated by comparing a product to a previously established scale. In the Quality management field several concepts are used to improve quality such as Total Quality Management, Six Sigma and Lean Production (e.g. Bendell 2006; Dahlgaard, Dahlgaard-Park 2006; Hellsten, Klefsjö 2000; Klefsjö et al. 2001). This has also been applied to improve the quality in the construction process (e.g. Kanji, Wong 1998; Tchidi et al. 2012; Viteikienè, Zavadskas 2007).

Work organization in the construction industry has traditionally been hierarchical. This is changing because of an increasing emphasis on worker motivation and participation (e.g. Söderberg et al. 1989). This thinking compliments Karasek and Theorell's (1990) Demand-ControlSupport model that gives workers a sense of ownership; hence a personal commitment to building quality.

As noted above, site managers have to handle structural matters and employee relations as well as contradictory and rapid change demands. Demands can come from a property developer, management, governmental authorities and unions. The managers who can balance relation, structure and change (see Arvonen 2002; Yukl 2012) are optimising construction activities and minimising stressors.

Leaders who involve workers and other participants in decision-making processes counteract negatives and create a more positive, effective and motivated culture in their work organisations. This leadership style is more focused on coaching and coordinating and less on giving orders - an important condition for successful integrated planning (Mikaelsson et al. 1992).

\section{Purpose and methods}

The overarching purpose of the original study was to develop, test, evaluate and refine a model of Integrated Planning for sustainable building site management. The model emulates Deming's (1986) four quality cycle stages of Plan, Do, Study and Act. The underlying purposes, aims and limitations of each of the five supporting studies are described in this article.

Secondly, the studies in this paper are a larger change study in imitation of a Deming cycle (Deming 1986). The first study can be seen as focusing on the Plan-stage, the second on the Do-stage, the third on the Study-stage and the fourth on the Act-stage. The fifth study goes back to the Plan-stage as a new loop in the cycle in the form of the development of an improved model. This multi-step five study process described here spanned the years 1985 to 2013.

The entire study is based on an action research approach with the aim that activities in each study shall improve the original Integrated Planning (IP) model. A practical aim of the studies is to publicize outcomes to encourage the use of Integrated Planning in construction projects around the world.

The aim of Study I, Integrated Planning (IP), was to find a model to increase the involvement of workers in building site planning. The study focused on learning how building workers can participate in an integrated planning model. Study participants used IP at three 
building sites. Datum was collected through observations and interviews with planning group members (Söderberg et al. 1989; Mikaelsson 1989).

An important part of Study II, Short-Time Building Schedules (SBS), was to identify planning models that minimized building site time pressures and work environment problems. The Integrated Planning model was tested at nine sites and evaluated in-depth at two building sites named here as "Aeolus" and "Fiskalen". The in-depth evaluation consisted of measuring the estimated time pressure and quality deviations throughout the two building processes. The two similar projects had different social dynamics and leader competencies. A self-estimating time pressure form (developed through earlier leader interviews) was completed by IP planning group participants (Mikaelsson et al. 1992). A twelve-point time pressure indicator scale went from "No time pressure" to "Impossible". The ideal score was expected to vary over time with a modest time pressure value in the beginning with an increasing need to save time during later, complicated finishing stages when many work groups had to be coordinated (this desired result is shown by the solid line in Fig. 2 below). To be avoided was an increase in time pressure in the final stages of the building process to make up for time lost earlier in the project. Predicted was that an increasing level of time pressure would create a negative work environment with high stress and poor quality (namely, the "not a desirable result" dotted line in Fig. 2 below). Each week during the study, the time pressure rating forms were collected and summarized. The information was shared with all planning group members. The planning group used the information to monitor whether they were in the desired time pressure range or were allowing time pressure to be greater than desired. Mikaelsson et al. (1992) complemented this empirical datum through site observations and interviews with building project staff. The study's results as depicted in Figure 2 were published in the book "Building at the threshold of the $21^{\text {st }}$ century" (Mikaelsson et al. 1992).

Study III, Production Planning, Work Organization and Leadership at a Building Construction Site (PWL), was primarily a follow-up review of Studies I and II. It evaluated the two studies to assess their impact on later building practices and to determine if and how building

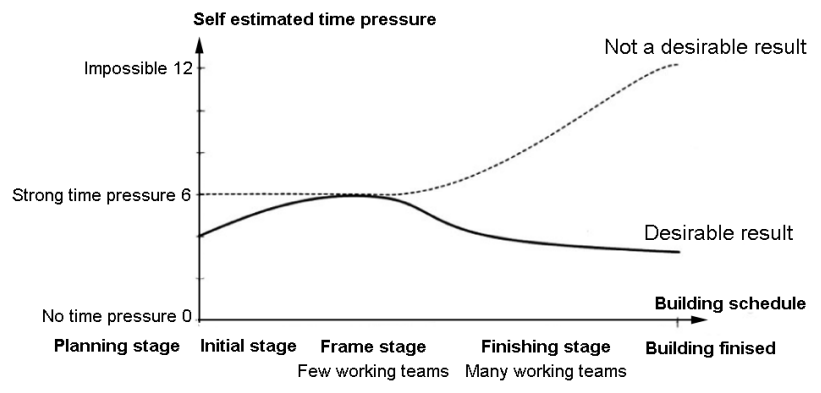

Fig. 2. Desired and not desired time pressure levels at different planning phases in Study II. The desired outcome has time pressure build, then fall companies were using their newly acquired skills in production planning, work organisation and leadership at building sites. The project was carried out in four steps: 1. Literature review; 2. Interviews with site managers; 3. Evaluation seminars; and 4. Documentation and reporting (Mikaelsson, Swensson 2006).

Relevant findings from the study were added to the original model. The model's development was interactive and iterative - a reflective approach, where practical opinions from workplaces and practitioners were considered, then integrated into the model's processes.

The aim with Study IV, Integrated Planning for Building Site Management, 2011-2013, was to study building site management models among Swedish multinational construction companies to determine to what extent elements from the IP model were being used in site planning processes.

The aim with Study V, Integrated Planning for Sustainable Building Production, was to formulate a refined IP model for sustainable construction management that can be tested and evaluated. Sustainable building production here means that there is focus on leadership, quality, environmental and work environment management in a building construction process.

\section{Results}

\subsection{Integrated planning (study I)}

The original IP model was designed by the IP project research group as part of a proposal. The model was based on research by Lars-Åke Mikaelsson $(1987,1989)$. It used a joint planning model format that integrated skills from the primary contractor, workers and craftspersons. Usually work planning is carried out by a staff production planner of the primary contractor in consultation with a site's manager. By creating a planning group that includes a foreman, worker representatives and a union safety delegate, their competencies and work environment concerns are made a part of practical, day-to-day planning and the overall planning process. A kind of legitimacy is given to site planning by the work force - they start to feel a sense of "ownership" for the site and its quality. A core planning group consisting of the site manager, production planner, supervisor, foreman, worker representatives and a union safety delegate make up a permanent planning group for Integrated Planning from the beginning through to the end of a building process. Foremen and workers from all teams at the site, including subcontractors, may be a part of the team during a particular process (e.g., a foreman who specializes in concrete is on the team while slab floors are poured). The number of planning group members can vary according to need. The model uses careful planning yet remains simple so that action can shift in response to change.

\subsection{Short-time building schedules (study II)}

When a building project time frame is short there is a natural tendency to speed up initial work; making up 
lost time at the end can be difficult. Nearing completion, planning can be more complex; more work groups are involved and all are active at the same time. This time pressure scenario tempts people to rush ahead without complete planning and documentation - the end is too distant and spending time on planning does not seem agile. This can be fatal, mistakes that are difficult to correct later are not apparent. Poor solutions when errors are later detected cause time-pressures to accumulate and build up at the end - despite efforts to avoid running out of time. The apparent alternative is to await the arrival of complete documentation - which usually leads to the same result - namely that if time available shrinks, time-pressure and stress increase (Mikaelsson et al. 1992; Mikaelsson, Swensson 2006).

An important part of Study II (SBS) was a test and evaluation of the IP model to study the effect of time pressure when using the model at two building projects. The two projects, Aeolus and Fiskalen, were constructed at the same time in the centre of the same city by the same building company. Aeolus was an office building and Fiskalen, a block of flats. The size of the two building projects was comparable and the building technology used for both was a site-built concrete frame. The organisations were similar; a site manager under the same director. At each site there were about thirty workers and craftspersons including subcontractors.

The planning groups (the site managers, supervisors, production planners, foremen, workers and union safety delegates) were set-up several weeks before start of construction for both projects. The social systems were different; Fiskalen had an experienced team who had worked together on many building projects. The site manager at Fiskalen was a skilful and committed leader. The staff for Aeolus were younger and not as experienced in working and planning together.

Aeolus can in many ways be regarded as an average building project. The site manager and the majority of the workers were younger. Socially, they functioned well together as there were many common interests. In the planning group many teambuilding activities were initiated. For example, physical training in the mornings for the entire team. The planning group activities focused on the main contractor's own staff of building workers. Subcontractor craftspersons were not as much involved. As a consequence, integrated planning activities ran well during the concrete frame building stage when most workers at the site were employed by the contractor. When the subcontractors came into the process it became more complicated. The planning group initially did not handle the change well but, improved.

Fiskalen started with a planning problem as the final plans from the architects and constructors were late. The project's initial phase was delayed two weeks. This created time pressure. The planning group worked to solve this problem by starting operations without detailed planning information. They understood the structure's rough layout and they felt that this was enough information to make sound initial phase planning decisions. They succeeded; the project was even ahead of schedule by the end of the frame building phase. Both the site manager and the foremen were committed and able to create a good example of integrated planning for all workers. Also, the subcontractor's craftspersons saw the planning process as valuable; conflicts between work groups were minimal. By the final stage it was apparent that integrated planning had kept the project on schedule and made it possible to avoid potential problems.

The evaluation of the IP model used a qualitative component that measured perceived time pressure. The researchers followed and observed building site progress. They held meetings with groups of participants and had discussions with individuals. They measured quantitatively through collection of data on Time Pressures and Quality Outcomes at both Aeolus and Fiskalen. The results concerning Time Pressures are presented in Figure 3. Both graphs in Figure 3 show the predicted outcomes of Figure 2. Imposed over these two lines are a light line showing actual measures at specific points in time and a heavy line extrapolating the time pressure measurements.

As shown in Figure 3, Aeolus had its highest time pressure at the later stages of the planning process while Fiskalen had the highest time pressure during the earlier planning phases. Generally, Fiskalen had a too high time pressure level during all planning phases. Probable is that the high level was caused by the planning group being given the building's plans late. This likely caused higher stress that was not overcome until late in the building project. However, the shape of the Fiskalen time pressure curve is closer to the desired curve shape - if the reason for time pressure is taken into account.

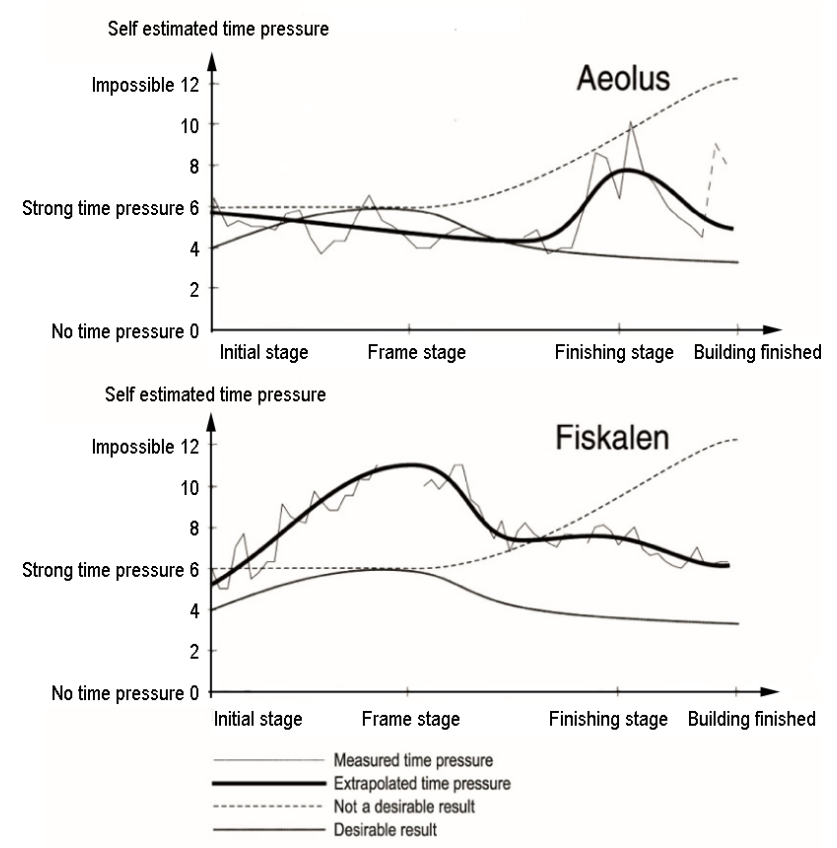

Fig. 3. Measurements of time pressure in the two building sites (Mikaelsson et al. 1992) 
The quality outcomes were measured as deviations from the specified standard that the building needed to follow. With respect to quality outcomes, there were clear differences between the two building sites. Aeolus had more deviations from plan specifications and thereby a lower quality level. Fiskalen had near zero deviations from plan specifications and a highest quality rating that could be assigned by this quality measurement system.

\subsection{Production planning, work organization and leadership (PWL) at the building site (study III)}

The results from Study III (Mikaelsson, Swensson 2006) found that many companies used planning models that contain similar basic elements to those in the IP model. Focus was mainly on time schedules; work environment issues were also important agenda topics during planning meetings. Sustainability and a balancing of all elements was not always present.

Study III makes a strong case for the need to improve leadership behaviours and leadership education to optimize the IP model and to integrate all facets of site management.

\subsection{Integrated planning for building site management (study IV)}

Study IV, as with Study III, found that the IP model illustrated in Figure 1 has become common among multinational Swedish construction companies. All four companies supporting the research have planning models that incorporate the basic elements of Integrated Planning. To a lesser extent, Quality, Environmental and Work Environment Management are part of planning processes. Apparent was that there was a continuing need to improve the model in terms of sustainability and leadership.

Both Studies III and IV suggest that healthy and effective site manager leadership behaviour and education need to be strengthened. Traditional production planning that focuses on time should be balanced with elements of quality, worker participation and environmental factors. All three dimensions of relation, structure and changeoriented leadership behaviour need to be incorporated. Leadership education for site managers and supervisors will need to emphasize balancing human factors with planning demands.

\subsection{Integrated planning for sustainable building production (study V)}

Study V combines the findings of the first four studies with leadership research to develop an improved IP model. Apparent was that a self-sustaining IP model uses flexible leadership-related QEW factors (quality, environmental and work environment) to broaden construction management techniques. In contrast, conventional building practices have planning and environmental factors fixed within relatively inflexible specifications and descriptions.

Leadership is, in general, an important factor for organizations (e.g., Arvonen 2002; Juran 1989; Yukl 2012).
This paper treats leadership as an influence process used to achieve organisational objectives.

In building site management it is a critical factor that acts to achieve an effective and more sustainable production process (Alinaitwe et al. 2007; Jitwasinkul, Hadikusumo 2011) and one key aspect in the leadership is to give opportunities for increased participation and decision-making among the craftspersons (Alinaitwe et al. 2009). This is consistent with the IP-model. Site managers are often promoted from among the most technically competent workers. Managers with a university level engineering education tend to regard site management as a career stepping-stone. For both groups the definition of good building site leadership is primarily based on factors such as social competence, detailed technical skills and functional knowledge. Seldom is leadership competence associated with knowledge of quality and the overall production process. Theoretical knowledge of and training in leadership for both promoted and university trained site managers is minimal (Mikaelsson, Swensson 2006). To improve IP there is a need to focus on leadership behaviours and education among site managers.

Early leadership behaviour theory had two dimensions: relation and structure orientation. In the 1990s the third dimension of change orientation became evident due to the increasing pressure for change imposed by society and organizations (Ekvall, Arvonen 1994; Yukl 1998). Relation oriented behaviours are used to improve human relations and human resources. Structure oriented behaviours are used to improve efficiency and process reliability. Change orientated behaviours are used to improve adaptation to external environments (Yukl 2012).

Studies have associated the three dimensions with multiple positive outcomes. High relation oriented behaviours are associated with better worker health (see Larsson 2010; Nyberg et al. 2005; Nyberg 2009; Skakon et al. 2010). High relation and high structure orientation relate to the outcome of effectiveness (see Andersen 1994; Mott 1972). High relation and structure orientation matched most closely with cost-effectiveness. For change effectiveness, high relation and change orientation were most closely connected (Arvonen, Pettersson 2002). For quality implementation, a varying of both high relation and high/low structure orientation has been identified (Turvey 1999). Studies of Theory Y oriented leadership values (McGregor 1960) connected with relation oriented behaviours were associated with positive quality outcomes and better worker health (Larsson 2010). Bass (1990) reported that both a purely relation oriented leadership and a combined style with both relation and structure orientation have positive effects on job satisfaction and productivity. In summary, relation oriented behaviours are important in work environments.

Two studies have identified and described common leadership behaviours at successful organisations, in terms of worker health and effectiveness (Larsson, Vinberg 2010). Nine different groups of leadership behaviours were identified: 1. Strategic and visionary leader 
role - these leaders maintain a holistic view and give their subordinates the opportunity to see their contributions within the organization. They clarify the organizational vision. 2. Communication and information these leaders create an infrastructure for information and communication with, for instance, regular meetings. The leaders communicate and strive to help employees see the value of continuous communication and information sharing. 3. Authority and responsibility - these leaders delegate both authority and responsibility, and do not control at a detailed level. These leaders trust their subordinates. 4. Learning culture - when projects and tasks are completed these leaders give constructive feedback; both positive and negative. They do not punish in the event of failure: they want to discuss how to improve. 5. Worker conversations - cross-functional discussions and dialogs are held where the leaders seriously listen and focus on worker ideas, wishes, and points of view. All subordinates have regular conversations with leaders. 6. Plainness and simplicity - these leaders encourage their subordinates to make decisions on their own which promotes rapid decision-making without time-consuming meetings. Each subordinate has a specific task, a responsibility area and enough authority to make decisions needed to accomplish assignments. 7. Humanity and trust - the leaders are deeply aware that mental and social well-being is a precondition for effective organizational performance. Communication and trust are keywords. 8. Visibility and walking around - these leaders frequently walk around in work areas and talk with every employee (called "Management by Walking Around"). They talk not only about the work; also about how they are feeling. 9. Reflective personal leadership - these leaders reflect upon their leadership practices, have a positive personal attitude (ibid.).

Based upon our findings from reviewing literature on construction leadership it is apparent that building site managers using the IP model need to incorporate the above healthy and effective, and relation-oriented leadership behaviours.

\section{Discussion}

The outcomes demonstrated that the IP model is effective in the construction industry. Also apparent is that that further development of the model can make it an even more useful tool. Study II emphasizes the importance of leadership in Integrated Planning Management. The building site Fiskalen had a leader with an effective style that more closely followed the IP model. It had a better time pressure curve and quality outcomes than the Aolous building. As noted earlier, some of this can be attributed to physical differences between the two sites and to the social dynamics at the more successful Fiskalen site. How Fiskalen's leader implemented the IP model gave workers and craftspersons more opportunities to exercise control over their own work. This self control factor has been seen as correlating with both good health and pro- ductivity (e.g. Karasek, Theorell 1990) and is an important element in modern quality management philosophies for creating high quality outcomes (e.g. Dahlgaard et al. 2002; Bergman, Klefsjö 2003).

Studies show that managers who reflect and continuously develop themselves have operations that are positive (e.g. Larsson 2010; Larsson, Vinberg 2010). These managers also understand that subordinates will work harder and be more productive when they are healthy and have control over their work environments. The sense of ownership that is generated from these behaviours is a powerful motivator as workers see that what they are doing is in their own self-interest. The IP model reflects this thinking; building workers are encouraged to take control over the planning of their work as a way to reduce completion times while promoting quality.

To develop the IP model from a sustainability and leadership perspective we present the model Integrated Planning for Sustainable Building Production (SBP). In it, some factors are given a greater emphasis and others added as shown in Figure 4. Sustainability here refers to the triple bottom-line model presented by for instance Persson (2009) and also used by other researchers in the building area (e.g. Viteikiene, Zavadskas 2007; Wang, Adeli 2014). The four additional factors rank equally and are discussed in the paragraphs that follow.

The first factor is a leadership perspective that can be learned; especially the healthy and effective behaviours described in the preceding section (Larsson 2010, 2012; Larsson, Vinberg 2010), and relation-oriented leadership behaviours (see Yuk1 2012). These leadership behaviours need to be used irrespective of context. Consistency allows subordinates know that they will always get a similar response. The healthy and effective leadership model

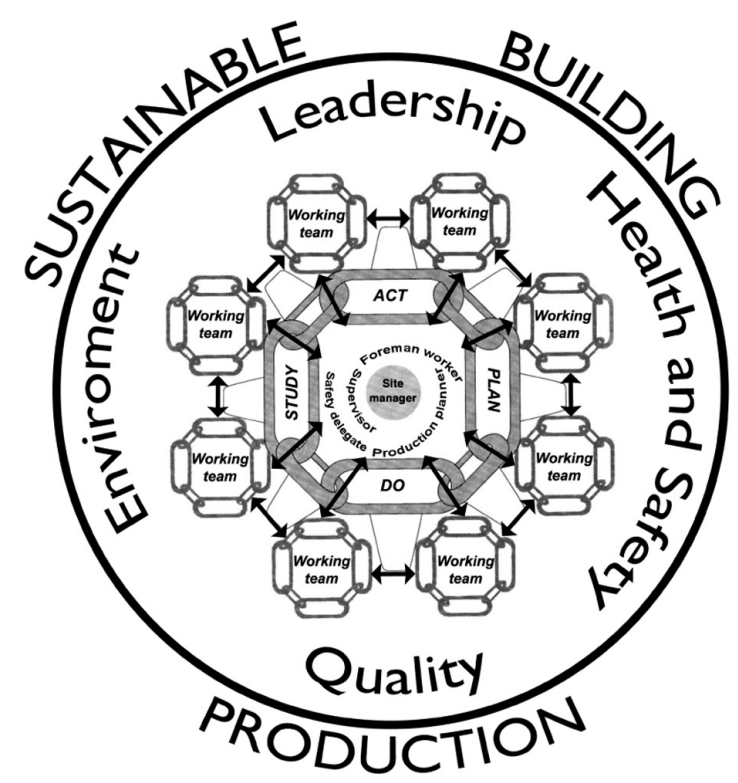

Fig. 4. Integrated Planning for sustainable building production (Refined model) 
contains the three behaviour dimensions of change, structure and relation orientation; using the model will significantly strengthen leader rapport with subordinates (Larsson, Vinberg 2010). For example, Fiskalen, the site with a stronger relation-orientation among the site's co-workers, had better results as shown by the eventual decline in the time pressure curve and increase in quality outcomes. Such relation-oriented behaviours follow McGregor's (1960) Theory Y leadership values. To best incorporate these behaviours into the new SBP model, managerial training and self-reflection is necessary. A theoretical component will help managers to understand what's being taught. For leaders coming from university engineering programmes, leadership factors also need to be incorporated into their curriculums.

The second factor added to the model is worker health and safety. The workforce health level should be frequently monitored to see how workers are feeling. This can be accomplished for instance, by promoting early warning health systems based on workforce health charting (see Larsson 2010). All persons at a building work site want to know that they have a good and safe work environment. Health and safety planning should be an integral part (Dèjus 2011; Dejjus, Antuchevičienė 2013).

The third factor to add is that a quality perspective must be encouraged at construction sites; a broadened quality definition that takes into consideration customer needs and expectations rather than only focusing on conformance with written specifications (see e.g., Bergman, Klefsjö 2003).

The fourth and last factor to include in a sustainable building production model is the impact a building site will have on its surrounding environment. Most companies have routines for environmental management. This would be enhanced by integration into the SBP model. Sustainability in the SBP model extends from the early stages of a building process to the end of a structure's life span.

Lastly, the SBP model is flexible and able to be scaled up or down to accommodate any size or type of construction. It can be used from the earliest stages of a building process.

\section{Conclusions}

As noted early in this article, its purpose was to develop, test, evaluate and refine an integrated planning (IP) model for use in the construction industry. Within the article we discussed the research used to validate the model and the final SBP model. The original model's performance was closely monitored at two building projects. The project Fiskalen most closely followed the model and consequently the quality of the finished building was much better than the other project (Aeolus). The Fiskalen building project was an IP model best practice application.

Taking this IP model the next step towards a Sustainable Building Production model (SBP) is illustrated in Figure 4. The improved model emphasizes develop- ing understanding of four critical factors: strengthening leadership (especially healthy and effective, relationoriented behaviours); increasing the focus on health and safety, especially worker self-estimates of health; basing a subjective quality perspective around modern quality management; and continually analysing the impact of an organization upon its surrounding physical environment.

The SBP model emphasises using education and training that develop leader skills in and knowledge of sustainable building site management. Managers who can add people skills to their technical skills are most likely able to learn and use the SPB model. These leaders learn to reflect on their values and behaviours so that they can respond to changes and new information - they move from being technically oriented to combining technological skills with the ability to lead others. Site managers using Larsson and Vinberg's (2010) nine behaviour groups can come to view healthy and effective leadership as a foundation in their building site management. They effectively integrate the three leadership dimensions of relation, structure and change with a special focus on a high level of relation orientation. When following this model, site managers have a closer relationship with individual workers. Lastly, construction project investments are substantial. Skilled and motivated leaders and workers are needed to make investment profitable. The SPB model supports investment while at the same time creating a construction organisation that develops humans, is sustainable and protective of the environment.

\section{References}

Alinaitwe, H.; Mwakali, J. A.; Hansson, B. 2007. Factors affecting the productivity of building craftsmen - studies of Uganda, Journal of Civil Engineering and Management 13(3): 169-176.

Alinaitwe, H.; Mwakali, J. A.; Hansson, B. 2009. Organizational effectiveness of Ugandan building firms as viewed by craftsmen, Journal of Civil Engineering and Management 15(3): 281-288. http://dx.doi.org/10.3846/1392-3730.2009.15.281-288

Andersen, J. A. 1994. Ledelse og effektivitet - teori og prøving [Leadership and effectiveness - theory and practical application]: Doctoral thesis. Lund University, Lund (in Norwegian).

Arvonen, J. 2002. Change, production and employees - an integrated model of leadership: Doctoral thesis. Stockholm University, Stockholm.

Arvonen, J.; Pettersson, P. 2002. Leadership behaviours as predictors of cost and change effectiveness, Scandinavian Journal of Management 18: 101-112. http://dx.doi.org/10.1016/S0956-5221(00)00009-9

Ballard, G. 2000. The last planner system of production control: $\mathrm{PhD}$ thesis. The University of Birmingham, Birmingham.

Bass, B. M. 1990. Bass \& Stogdill's handbook of leadership: Theory, research \& managerial applications. New York: Free Press. 1184 p.

Bendell, T. 2006. A review and comparison of six sigma and the lean organisations, The TQM Magazine 18(3): 255-262. http://dx.doi.org/10.1108/09544780610659989

Bergman, B.; Klefsjö, B. 2003. Kvalitet från behov till användning [Quality from customer needs to customer satisfaction]. Lund, Sweden: Studentlitteratur. 704 p. 
Crosby, P. B. 1979. Quality is free: the art of making quality certain. New York: McGraw-Hill. 309 p.

Dahlgaard, J. J.; Dahlgaard-Park, S. M. 2006. Lean production, six sigma quality, TQM and company culture, The TQM Magazine 18(3): 263-281.

http://dx.doi.org/10.1108/09544780610659998

Dahlgaard, J. J.; Kristensen, K.; Kanji, G. K. 2002. Fundamentals of total quality management. UK: Nelson Thornes Ltd. $372 \mathrm{p}$.

Dejus, T. 2011. Safety of technological projects using multicriteria decision making methods, Journal of Civil Engineering and Management 17(2): 177-183. http://dx.doi.org/10.3846/13923730.2011.576809

Dejus, T.; Antuchevičienè, J. 2013. Assessment of health and safety solutions at a construction site, Journal of Civil Engineering and Management 19(5): 728-737. http://dx.doi.org/10.3846/13923730.2013.812578

Deming, W. E. 1986. Out of the crisis. Cambridge: MIT. 507 p.

Ekvall, G.; Arvonen, J. 1994. Leadership profiles, situation and effectiveness, Creativity and Innovation Management 3(3): 139-161. http://dx.doi.org/10.1111/j.1467-8691.1994.tb00168.x

Hellsten, U.; Klefsjö, B. 2000. TQM as a management system consisting of values, techniques and tools, The TQM Magazine 12(4): 238-244.

http://dx.doi.org/10.1108/09544780010325822

Jitwasinkul, B.; Hadikusumo, B. H. W. 2011. Identification of important organisational factors influencing safety work behaviours in construction projects, Journal of Civil Engineering and Management 17(4): 520-528. http://dx.doi.org/10.3846/13923730.2011.604538

Juran, J. M. 1989. Juran on leadership for quality. New York: The Free Press. 384 p.

Kanji, G. K.; Wong, A. 1998. Quality culture in the construction industry, Total Quality Management 9(4/5): 133-140. http://dx.doi.org/10.1080/0954412988758

Karasek, R.; Theorell, T. 1990. Healthy work: stress, productivity, and the reconstruction of working life. New York: Basic Books. 381 p.

Klefsjö, B.; Wiklund, H.; Edgeman, R. L. 2001. Six sigma seen as a methodology for total quality management, Measuring Business Excellence 5(1): 31-35. http://dx.doi.org/10.1108/13683040110385809

Larsson, J. 2010. Leadership for quality, effectiveness and health in organisations: Doctoral thesis. Mid Sweden University, Östersund.

Larsson, J. 2012. Ledarskapsbokslut [Leadership closure]. Östersund: Metodicum. 99 p. (in Swedish).

Larsson, J.; Vinberg, S. 2010. Leadership behaviour in successful organisations - universal or situation-dependent?, TQM \& Business Excellence 21(3): 317-334. http://dx.doi.org/10.1080/14783360903561779

McGregor, D. 1960. The human side of enterprise. New York: McGraw-Hill. 256 p.

Mikaelsson, L.-Å. 1987. Arbetsvetenskapliga perspektiv [Work science perspectives]: Licentiate thesis. Lund University, Lund, Sweden (in Swedish).

Mikaelsson, L.-Å. 1989. Byggnadsarbetares involvering i planeringen av byggprojekt [Building worker involvement in the planning of a building construction project]: Doctoral thesis. Sundsvall/Härnösand \& Lund: Mid Sweden University \& Lund University, Lund, Sweden (in Swedish).

Mikaelsson, L.-Å.; Bengtsson, S.; Lindell, J.; Larsson, P. 1992. Bygga inför 2000-talet [Building construction at the threshold of the $21^{\text {st }}$ century]. Stockholm: Byggförlaget. 80 p. (in Swedish).

Mikaelsson, L.-Å.; Swensson, L.-G. 2006. Bygga för 2000 talet [Building for the $21^{\text {st }}$ century]. Östersund \& Lund: Mid Sweden University \& Lund University. 112 p. (in Swedish).

Mikaelsson, L.-Å. 2011. Hållbar byggproduktion - Produktionsplanering, arbetsorganisation och ledarskap på byggarbetsplatsen [Sustainable building production - production planning, work organization and leadership at building construction sites]. Östersund: Mid Sweden University (in Swedish).

Mott, P. E. 1972. The characteristics of effective organizations. New York: Harper \& Row. 227 p.

Nyberg, A.; Bernin, P.; Theorell, T. 2005. The impact of leadership on the health of subordinates, SALTSA. Research Report no. 1. National Institute for Working Life, Stockholm.

Nyberg, A. 2009. The impact of managerial leadership on stress and health among employees: Doctoral thesis. Karolinska Institutet, Stockholm.

Persson, U. 2009. Management of sustainability in construction works: Doctoral thesis. Lund University, Lund, Sweden.

Skakon, J.; Nielsen, K.; Borg, V.; Guzman, J. 2010. Are leaders' well-being, behaviours and style associated with the affective well-being of their employees? A systematic review of three decades of research, Work \& Stress 24(2): 107-139. http://dx.doi.org/10.1080/02678373.2010.495262

Sundin, L. 2009. Work-related social support, job demands and burn-out - Studies of Swedish workers, predominantly employed in health care: Doctoral thesis. Karolinska Institutet, Stockholm.

Söderberg, J.; Schröder, C.; Korhonen, M.; Mikaelsson, L.-Å.; Persson, M.; Swensson, L.-G. 1989. Integrerad planering. Försök med arbetstagarmedverkan vid planering av byggprojekt [Integrated planning. Attempts with subordinate collaboration when planning a building project]. Lunds University, Lund, Sweden. 3 p. (in Swedish).

Tchidi, F. M.; He, Z.; Li, Y. B. 2012. Process and quality improvement using six sigma in construction industry, Journal of Civil Engineering and Management 18(2): 158-172. http://dx.doi.org/10.3846/13923730.2012.657411

Turvey, R. D. 1999. The effects of leadership style on total quality management implementation: Doctoral thesis. University of Missouri-Rolla, Missouri-Rolla.

Viteikienè, M.; Zavadskas, E. K. 2007. Evaluating the sustainability of Vilnius city residential areas, Journal of Civil Engineering and Management 13(2): 149-155.

Wang, N.; Adeli, H. 2014. Sustainable building design, Journal of Civil Engineering and Management 20(1): 1-10. http://dx.doi.org/10.3846/13923730.2013.871330

Yukl, G. 1998. An evaluative essay on current conceptions of effective leadership, European Journal of Work and Organizational Psychology 8(1): 33-48. http://dx.doi.org/10.1080/135943299398429

Yukl, G. 2012. Leadership in organisations. London: Prentice Hall. 508 p.

Lars-Åke MIKAELSSON. He is working as a Senior Lecturer in Sustainable Building Production and Human Work Sciences at Mid Sweden University's Östersund Campus. His Research focus is work organisation in the building industry.

Johan LARSSON. He is working as a Senior Lecturer at the Centre for Musculoskeletal Research in the Department of Occupational and Public Health Sciences at the University of Gävle. His research focus is leadership, organisation and management control in relation to health, quality and effectiveness. 